\title{
EMBRACING SOCIAL MEDIA TO IMPROVE EFL LEARNERS' ENGLISH SKILL
}

\author{
Dwi Iswahyuni ${ }^{1}$ \\ ${ }^{1}$ Universitas Bina Sarana Informatika \\ ${ }^{1}$ dwi.dhs@bsi.ac.id
}

\begin{abstract}
Regarding the importance of exploring the use of social media to enhance English skill, this study investigated the use of social media to improve English skill of EFL learners especially non-English college students. The objective of this study was to find out in what ways social media can contribute to the improvement of EFL learners' English skill. The research method employed in this study was descriptive qualitative method. In gaining data, this study used questionnaire and observation. The results showed that almost all respondents took advantage of social media to learn English. Some social media used were YouTube, WhatsApp, Instagram, Facebook, Twitter, TikTok, etc. The respondents revealed that by the use of social media, their reading skill (97.3\% of the respondents), their writing skill ( $94.6 \%$ of the respondents), their vocabulary mastery (91.9\% of the respondents), their listening skill (89.2\% of the respondents), their speaking skill (86.5\% of the respondents), their grammar mastery (83.8\% of the respondents) could be improved. Based on the findings of the study, it can be inferred that social media can contribute to the improvement of EFL learners' English skill in many ways including reading skill, writing skill, vocabulary mastery, listening skill, speaking skill, and grammar mastery.
\end{abstract}

Keywords: EFL Learners, English Skill, Social Media

\section{INTRODUCTION}

It is inevitably that mastering English is very significant nowadays. It is an international language, in which it is used to communicate with people around the world. Moreover, it is used to serve various purposes such as to provide information in various fields (Rao, 2019). In addition, by having a good English skill, people can have better opportunities for their careers (Rini, 2014).

Seeing the importance of English, people endeavor to master this language. However, they sometimes encounter some obstacles when learning English. In speaking skill, the EFL (English as a Foreign Language) learners may face some problems like psychological problems (lack of self-confidence and anxiety), linguistic problems, grammar, vocabulary, and pronunciation (Fitriani et al., 2015). Azmi et al. state that the difficulties encountered in listening comprehension are quality of recorded materials, cultural differences, accent, unfamiliar vocabulary, and length and speed of listening (Gilakjani \& Sabouri, 2016). In accordance with problems in reading comprehension, the biggest reading comprehension problem is with semantics in which unfamiliar vocabulary become the major problem in comprehending English texts (Kasim \& Raisha, 2017). Moreover, according to Ashraf, the major problems in writing encountered by ESL learners are related to the use of tenses, articles, and prepositions (Ismiati \& Pebriantika, 2020).

There are several ways to overcome the obstacles encountered by EFL learners in learning English. One of them is by learning English through social media. The term "social media" 
refers to "the wide range of internet-based and mobile services that allow users to participate in online exchanges, contribute user-created content, or join online communities" (Dewing, 2010). Social media are new forms of media in which people can interact one another such as sharing ideas/ information with the use of digital platform (Manning, 2014). In other words, social media are such kinds of internet-based media that enable us to interact or communicate one another either in small or large scale. Social media have evolved over the years. The examples of social media are WhatsApp, YouTube, Instagram, Facebook, Twitter, etc.

Due to the advanced technology and the availability of internet, it seems that social media has played a significant role in our lives nowadays. We can utilize social media for many purposes, including for learning English. Furthermore, during the pandemic faced by the world since 2020, the teaching learning process has been moved to online learning. Various social media might be employed here.

Anwas et al. conducted a study about the usage of social media for enhancing English skill (Anwas et al., 2020). The objective of their study was to find out students' intensity of using English-language social media content. Based on the data analysis from quantitative approach and survey method among Senior High School students in Jakarta, it was found out that students' intensity who used English-language social media content was low, students' perception of English skill in reading and writing was good, while students' perception of listening and speaking was still low.

Another study related to the use of social media for English learning was carried out by Namaziandost and Nasri (2019). They investigated the impact of social media on EFL learners' speaking skill. In this survey study, the questionnaires were distributed to EFL teachers and learners. The findings showed that the frequent usage of social media by EFL teachers and students constituted a significant impact on both users. Moreover, it was very important for teachers to employ the appropriate social media to enrich their teaching process and to encourage students to be able to interact and communicate effectively in English (Namaziandost \& Nasri, 2019).

A study about the effects of information and communication technology and social media in developing student's writing skill was undertaken by Bakeer (2018). The aims of this study were to find out undergraduate EFL learners' writing problems and the effect of ICT and social media in developing positive attitudes and improving students' proficiency in writing English at the university level (Bakeer, 2018). A number of 72 undergraduate students were involved in this study in which they were divided into a control group and an experimental group. The results revealed that the undergraduate EFL learners encountered various problems in their writing, such as in terms of morphology and syntax, lack of knowledge of the appropriate words, cohesion and mechanical mistakes, etc. Furthermore, by using social media, their interest in learning English was increased and their writing skill was improved. In other words, the integration of ICTs and social media had a positive effect in developing students' writing skill.

Regarding the importance of exploring the use of social media to enhance English skill, this study is going to investigate the use of social media to improve English skill of EFL learners. Moreover, different from the previous studies, this study focuses on the use of social media to boost English skill of EFL learners especially non-English college students. The research problem formulated in this study is in what ways social media can contribute to the 
improvement of EFL learners' English skill. The objective of this study, then, is to find out in what ways social media can contribute to the improvement of EFL learners' English skill.

\section{METHOD}

The research design used in this study is a descriptive qualitative method. Accoding to Maanen (Merriam, 2009), qualitative research is "an umbrella term covering an array of interpretive techniques which seek to describe, decode, translate, and otherwise come to terms with the meaning, not the frequency, of certain more or less naturally occuring phenomena in the social world". In other words, this kind of method is closely related to interpretive techniques and describing something or phenomena.

The focus of this study is about how social media can enhance English skill of EFL (English as a Foreign Language) learners. Here, the participants of the study are 38 non-English college students and a lecturer in a private university in Indonesia.

To gain the data, it needs instruments. The research instruments used in this study are questionnaire and observation. Wilson and McLean reveal that "questionnaire is a widely used and useful instrument for collecting survey information, providing structured, often numerical data, being able to be administered without the presence of the researcher, and often being comparatively straightforward to analyse" (Cohen et al., 2007). Here, the employed questionnaire is the combination of open-ended and closed-ended questionnaires. Open-ended questionnaire contains open-ended questions in which there are no predetermined options of answers and the respondents are asked to give their own answers (Cargan, 2007). Meanwhile, closed-ended questionnaire contains closed-ended questions in which there are response categories provided in the questionnaire (Johnson \& Christensen, 2010).

The data collecting steps start from creating the questionnaire. The questions are about the importance of English, how the respondents learn English, the obstacles they find when learning English, the use of social media to learn English, and whether the social media can enhance their English skills (listening, speaking, reading, writing skills) or not. After the questionnaire has been made, the writer shares the questionnaire to the respondents through google form. Furthermore, the writer, who is the lecturer, also does an observation when social media are employed in her classes.

Having gained the data, the writer does the analysis. The results of questionnaire and observation are analyzed. The findings are described based on the aim of the study, which is about the contribution of social media in enhancing EFL learners' English skill. At last, the writer draws the conclusion.

\section{RESULTS AND DISCUSSION}

\section{Results}

This study investigated in what ways social media could improve English skill of EFL learners. The findings of this study were based on the questionnaire and observation. The results of these two instruments were as follows. 
The Results of Questionnaire

There were 14 questions in the questionnaire. It encompassed the importance of learning English, how the respondents learned English, the obstacles they found when learning English, the use of social media to learn English, and whether the social media could enhance their English skills (listening, speaking, reading, writing skills) or not.

a. The importance of learning English

All of the respondents perceived that English was very important to master. English was international language. It was a means of communication with people around the world. In addition, many journals and books with full of insights were also written in English. With good English proficiency, people could understand the contents so that they could enrich their knowledge. Moreover, English skill frequently became one of the requirements when applying job. By having a good English skill, people might easily get jobs. Furthermore, mastering English was also very beneficial since it was used in many fields, such as, education, technology, business, tourism, etc. In technology field, English became the language which was frequently used to deliver the instructions or information of a tool or system. It seemed that IT (information technology) couldn't be separated with English. In tourism field, it was also employed for many purposes, such as promoting destination or giving information related to tourism.

b. How the respondents learned English

Most of the respondents revealed that they learned English through formal learning at school and college. In addition to formal learning, some of them also joined English courses and took advantage of social media (such as YouTube) to hone their English skill. Moreover, some of them also used websites and applications to improve their English skill. Furthermore, movies, songs, games, and articles in English were several contents they used to learn English.

c. The obstacles the respondents encountered when learning English

Some obstacles the respondents encountered when learning English were in terms of vocabulary, grammar, pronunciation, reading comprehension, syntax, self-confidence when speaking, listening, and motivation.

d. The use of social media to learn English

Almost all of the respondents $(97.4 \%)$ said that they had ever used social media (such as YouTube, WhatsApp, Facebook, etc.) to learn English or access English contents. It was portrayed through Figure 1.

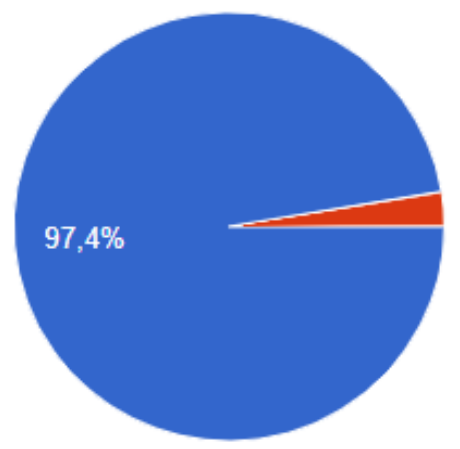

Figure 1. The use of social media to learn English

e. The frequency of social media usage for learning English

Most of the respondents said that they sometimes used social media to learn English. The details of this issue were depicted through Table 1. 
Table 1. The frequency of social media usage to learn English

\begin{tabular}{cc}
\hline Frequency & $\begin{array}{c}\text { Percentage } \\
\text { (respondents) }\end{array}$ \\
\hline often & $37.8 \%$ \\
\hline sometimes & $54.1 \%$ \\
\hline rarely & $8.1 \%$ \\
\hline
\end{tabular}

f. Kinds of social media used by the respondents to learn English

Based on the results of the questionnaire, there were several social media used by the respondents to learn English. The most used social media were YouTube and Instagram. The other social media used to learn English were Facebook, TikTok, WhatsApp, Twitter, Snapchat, Telegram, and Path. Some respondents also revealed that they used some applications like Brainly, Duolingo, U-dictionary, and Cake. Moreover, there were also respondents who used some websites containing English materials, Google, and Google Translate to hone their English skill.

g. English contents accessed in social media

The most frequent accessed English contents in social media were movies and conversation videos. The other ones included songs, blogs, news, tutorials, conversation recording, and talkshow.

h. The improved English skill by the use of social media

Based on the results of the questionnaire, it was found that all skills of language learning (listening, speaking, reading, writing) could be enhanced through the use of social media. It was further depicted through Table 2 .

Table 2. The improved English skill by the use of social media

\begin{tabular}{ccc}
\hline \multirow{2}{*}{ Skill/ Mastery } & \multicolumn{2}{c}{$\begin{array}{c}\text { The percentage of the } \\
\text { respondents related to the } \\
\text { improvement }\end{array}$} \\
\cline { 2 - 3 } & Yes & No \\
\hline listening skill & $89.2 \%$ & $10.8 \%$ \\
\hline speaking skill & $86.5 \%$ & $13.5 \%$ \\
\hline reading skill & $97.3 \%$ & $2.7 \%$ \\
\hline writing skill & $94.6 \%$ & $5.4 \%$ \\
\hline grammar mastery & $83.8 \%$ & $16.2 \%$ \\
\hline vocabulary mastery & $91.9 \%$ & $8.1 \%$ \\
\hline
\end{tabular}

Based on Table 2, it could be known that by the use of social media, their reading skill (97.3\% of the respondents), their writing skill (94.6\% of the respondents), their vocabulary mastery (91.9\% of the respondents), their listening skill (89.2\% of the respondents), their speaking skill ( $86.5 \%$ of the respondents), their grammar mastery ( $83.8 \%$ of the respondents) could be improved. Here, the highest improvement belonged to the improvement of reading skill.

The Results of Observation

To enrich the research data, the writer (the lecturer of the respondents) also did an observation. She observed the social media usage in her class. The writer employed social media to teach English. The social media she used were YouTube and WhatsApp. Based on the results of 
observation, these social media seemed very beneficial, either increasing the students' (the respondents') interest during teaching learning process and improving their English skill.

The writer made use of WhatsApp to improve the students' listening skill, pronunciation, and vocabulary mastery. She sent a recording or voice note in the WhatsApp group and after that, the students were asked to guess the words or expressions uttered. Here, the students were very enthusiastic to guess the words or expressions. In the other occasion, the writer sent recording or voice note of some expressions, and the students were required to respond the expressions uttered. After the students gave the responses, the writer chose the correct one and if there were no correct responses, the writer informed the correct one. In this case, the students' listening skill could be improved. Moreover, by guessing the words or expressions, the students also could learn how to pronounce them correctly and enrich their vocabulary.

In addition to WhatsApp, YouTube, which was also one of social media, was also very fruitful to boost the respondents' English skill. At first, the writer shared the links of some videos in YouTube and then the students were assigned to watch the videos and retell what they had watched by texting in the WhatsApp group. Here, they were encouraged to hone their listening skill and writing skill.

\section{Discussion}

As time goes by, the presence of social media was very beneficial in many fields, including for education field. Moreover, during the pandemic, the teaching learning process was shifted to online learning. The teacher or the lecturer could not meet the students directly one another. In this case, social media could become the bridge between the teachers or lecturers and their students, and of course, the students were sometimes encouraged to do self-learning. Especially in English learning, EFL learners could take advantage of social media to enhance their English skill due to its flexibility and interesting features.

The findings of the study showed that there were many obstacles EFL learners encountered when learning English and social media could be used to overcome them. Almost all respondents took advantage of social media to learn English. Some social media used were YouTube, WhatsApp, Instagram, Facebook, Twitter, TikTok, etc. The usage of social media could improve EFL learners' English skill including listening skill, speaking skill, reading skill, writing skill, grammar mastery, and vocabulary mastery. The highest percentage was for the improvement of reading skill and the least percentage was for grammar mastery. In terms of reading skill, EFL learners could hone this skill by reading some English contents in social media such as news, tips, etc. Meanwhile, in terms of speaking skill, EFL learners could talk with native speakers through social media. Furthermore, EFL learners could watch videos or listen to recording/ songs in English through social media to improve their listening skill. In this case, EFL learners could also enrich their vocabulary. In addition, when they read English comments in social media, their vocabulary mastery might also be improved. Moreover, EFL learners could hone their writing skill through social media, such as by posting something in English in their social media. In addition, EFL learners could learn grammar by following some accounts in social media which gave insights about grammar.

\section{CONCLUSION}

Nowadays, social media can be utilized to overcome the obstacles EFL learners encounter when learning English. Regarding the importance of exploring the use of social media to enhance 
English skill, this study investigates the use of social media to improve English skill of EFL learners especially non-English college students. Based on the findings of the study, it can be inferred that social media can contribute to the improvement of EFL learners' English skill in many ways including reading skill, writing skill, vocabulary mastery, listening skill, speaking skill, and grammar mastery.

\section{ACKNOWLEDGMENTS}

This study is an independent research and the author would like to thank students of Universitas Bina Sarana Informatika who have supported this research.

\section{REFERENCES}

Anwas, E. O. M., Sugiarti, Y., Permatasari, A. D., Warsihna, J., Anas, Z., Alhapip, L., Siswanto, H. W., \& Rivalina, R. (2020). Social media usage for enhancing english language skill. International Journal of Interactive Mobile Technologies, 14(7), 41-57. https://doi.org/10.3991/IJIM.V14I07.11552

Bakeer, D. A. M. (2018). Effects of Information and Communication Technology and Social Media in Developing Students' Writing Skill: A Case of Al-Quds Open University. International Journal of Humanities and Social Science, 8(5). https://doi.org/10.30845/ijhss.v8n5a5

Cargan, L. (2007). Doing Social Research. Rowman \& Littlefield Publishers, Inc. https://www.google.co.id/books/edition/Doing_Social_Research/LeHXAQAAQBAJ?hl= en\&gbpv=1\&dq=Cargan, + L.+(2007).+Doing+Social+Research.+Lanham:+Rowman+\% 26+Littlefield+Publishers, + Inc.\&printsec $=$ frontcover

Cohen, L., Manion, L., \& Morrison, K. (2007). Research Methods in EducCohen, L., Manion, L., \& Morrison, K. (2007). Research Methods in Education. Education (Vol. 55, pp. 469470). doi:10.1111/j.1467-8527.2007.00388_4.xation. In Education (Vol. 55). http://www.tandfonline.com/doi/abs/10.1111/j.1467-8527.2007.00388_4.x

Dewing, M. (2010). Social Media : An Introduction. In Library Of Parliament's In Brief.

Fitriani, D. A., Apriliaswati, R., \& Wardah. (2015). A study on student' s English epeaking problems in speaking performance. Jurnal Pendidikan Dan Pembelajaran Untan, 4(9), 113. http://jurnal.untan.ac.id/index.php/jpdpb/article/viewFile/11345/10753

Gilakjani, A. P., \& Sabouri, N. B. (2016). Learners' Listening Comprehension Difficulties in English Language Learning: A Literature Review. English Language Teaching, 9(6), 123. https://doi.org/10.5539/elt.v9n6p123

Ismiati, I., \& Pebriantika, E. (2020). Designing Strategies For University Students' Writing Skill. Journal of Languages and Language Teaching, 8(1), 8. https://doi.org/10.33394/jollt.v8i1.2210

Johnson, B., \& Christensen, L. (2010). Educational Research, Quantitative, Qualitative, and Mixed Approaches (Fourth). SAGE Publications, Inc. https://www.google.co.id/books/edition/Educational_Research/b2ujHWrRpVQC?hl=id\& gbpv=1\&dq=Johnson, + B.+and+Christensen, + L.+(2012).+ Educational+Research+Fourth +Edition.+Thousand+Oaks:+SAGE+Publications, +Inc.\&pg=PR4\&printsec=frontcover

Kasim, U., \& Raisha, S. (2017). EFL Students' Reading Comprehension Problems: Linguistic And Non-Linguistic Complexities. English Education Journal, 8(3), 308-321.

Manning, J. (2014). Definition and Classes of Social Media. Encyclopedia of Social Media and Politics, 1158-1162.

Merriam, S. B. (2009). Qualitative research: A guide to design and implementation. In The JosseyBass higher and adult education series (Vol. 2nd). 
https://doi.org/10.1097/NCI.0b013e3181edd9b1

Namaziandost, E., \& Nasri, M. (2019). The Impact of Social Media on EFL Learners' Speaking

Skill: A Survey Study Involving EFL Teachers and Students. Journal of Applied Linguistics and Language Research, 6(3), 199-215.

Rao, P. S. (2019). The importance of english in the modern era. Asian Journal of Multidimensional Research (AJMR), 8(1), $7 . \quad$ https://doi.org/10.5958/22784853.2019.00001.6

Rini, J. E. (2014). English in Indonesia: Its position among other languages in Indonesia i. Beyond Words, 2(2), 19-39. http://journal.wima.ac.id/index.php/BW/article/view/591 